\title{
Photosymbiotic ascidians in Singapore: turbid waters may reduce living space
}

\author{
Shih-Wei Su', Euichi Hirose², Serina Lee Siew Chen ${ }^{3}$, Michael Hin-Kiu Mok ${ }^{4}$ \\ I Department of Marine Biotechnology and Resources, National Sun Yat-sen University, Kaohsiung 80424, \\ Taiwan 2 Faculty of Science, University of the Ryukyus, Nishihara, Okinawa 903-0213, Japan 3 Tropical Ma- \\ rine Science Institute, National University of Singapore, Singapore 119227, Republic of Singapore 4 Institute \\ of Marine Biology, National Sun Yat-sen University, Kaobsiung 80424, Taiwan
}

Corresponding author: Shih-Wei Su (tunicate.su@gmail.com)

Academic editor: L. Penev | Received 21 February 2012 | Accepted 27 May 2013 | Published 30 May 2013

Citation: Su S-W, Hirose E, Chen SLS, Mok MH-K (2013) Photosymbiotic ascidians in Singapore: turbid waters may reduce living space. ZooKeys 305: 55-65. doi: 10.3897/zookeys.305.4893

\begin{abstract}
The photosymbiotic ascidian fauna at Changi Beach, Pulau Semakau, Sentosa and St. John's Island, Singapore were surveyed. A total of five species, Diplosoma simile, Lissoclinum bistratum, L. punctatum, L. timorense and Trididemnum cyclops, were recorded, with L. timorense and T. cyclops being newly recorded in Singapore. However, no photosymbiotic species were found at Changi Beach probably due to the polluted waters in the region. Coastal development has caused Singapore waters to become turbid, leading to decrease in suitable habitats for photosymbiotic ascidians. Clean waters in Pulau Semakau probably provide a better environment for the growth of photosymbiotic ascidians and this area has a greater variety of these ascidians than the other areas in Singapore. Each of the five species has also been recorded in the Ryukyu Archipelago (Japan) and three species (Diplosoma simile, Lissoclinum bistratum and Trididemnum cyclops) have also been recorded in Taiwan.
\end{abstract}

\section{Keywords}

Algal symbiosis, Ascidian, Biogeography, Coral reefs, Didemnidae

Copyright Shih-Wei Su et al. This is an open access article distributed under the terms of the Creative Commons Attribution License 3.0 (CC-BY), which permits unrestricted use, distribution, and reproduction in any medium, provided the original author and source are credited. 


\section{Introduction}

Photosymbioses have been known in some colonial ascidians of the family Didemnidae in tropical and subtropical waters. Photosymbionts such as Prochloron and Synechocystis are cyanobacteria (see Parry and Kott 1988; Lewin and Cheng 1989; Hirose et al. 2009b). About 30 species in four didemnid genera were described as host species (Kott 2001). Most of these ascidian hosts always harbor particular cyanobacterial species (i.e., obligate symbiosis), whereas some hosts occasionally harbor the photosymbionts (i.e., facultative symbiosis). Recent taxonomic studies described seven photosymbiotic ascidians from the Ryukyu Archipelago of Japan as new species (Oka et al. 2005; Hirose and Oka 2008; Hirose and Hirose 2009, 2011; Hirose et al. 2009a).

The biogeographic survey of photosymbiotic didemnids in Ryukyus has recorded the current distribution range for each species. To date, at least 20 photosymbiotic species are known to be distributed in Japan, mainly in the Ryukyu Archipelago (Hirose in press, and references therein). The number of species gradually decrease northward in the Ryukyu Archipelago, which ranges from around $24^{\circ} \mathrm{N}$ to $31^{\circ} \mathrm{N}$. Nineteen species have been recorded from the Yaeyama Islands (the southernmost island group: at ca. $24^{\circ} \mathrm{N}$ ), whereas only four species were recorded from Yakushima and Tanegashima (the northernmost islands: at ca. $\left.30^{\circ}-31^{\circ} \mathrm{N}\right)$. Taiwan $\left(21^{\circ}-25^{\circ} \mathrm{N}\right)$ is positioned close to the southernmost island group of the Ryukyu Archipelago (i.e., the Yaeyama Islands), and 10 species in total were recorded from Kenting (southern Taiwan) and Lyudao (off the southeast coast of Taiwan), but no photosymbiotic species were found in Keelung (located in northern Taiwan), probably due to the cold surface water in winter (ca. $16^{\circ} \mathrm{C}$ ) in that region (Hirose and Nozawa 2011; Hirose and Su 2011).

Singapore is positioned at the equator and there are only a few reports on the ascidian fauna in Singapore waters (e.g., Berrill 1950; Millar 1975, 1988). Regarding photosymbiotic ascidians from Singapore, Kott (1982) listed three species, namely Lissoclinum bistratum, L. punctatum, and Diplosoma simile. Moreover, occurrence of some other photosymbiotic ascidians was reported as "green gum drops ascidians" awaiting identification (Wild Singapore Homepage, http://www.wildsingapore. $\mathrm{com} /$ wildfacts/ascidiacea/greengumdrop.htm). In view of the numbers of species recorded in Japan and Taiwan, more photosymbiotic species were expected to be found in Singapore.

During 2009-2011, we surveyed the photosymbiotic ascidians at Changi Beach, Pulau Semakau, Sentosa and St. John's Island, Singapore in collaboration with the Tropical Marine Science Institute, National University of Singapore. Herein, five photosymbiotic didemnid species were reported as additions to the marine benthic fauna of Singapore.

\section{Material and methods}

Ascidian colonies were collected by snorkeling in the shallow subtidal zone. Samples were photographed in situ before being collected. Collection sites were as follows: 


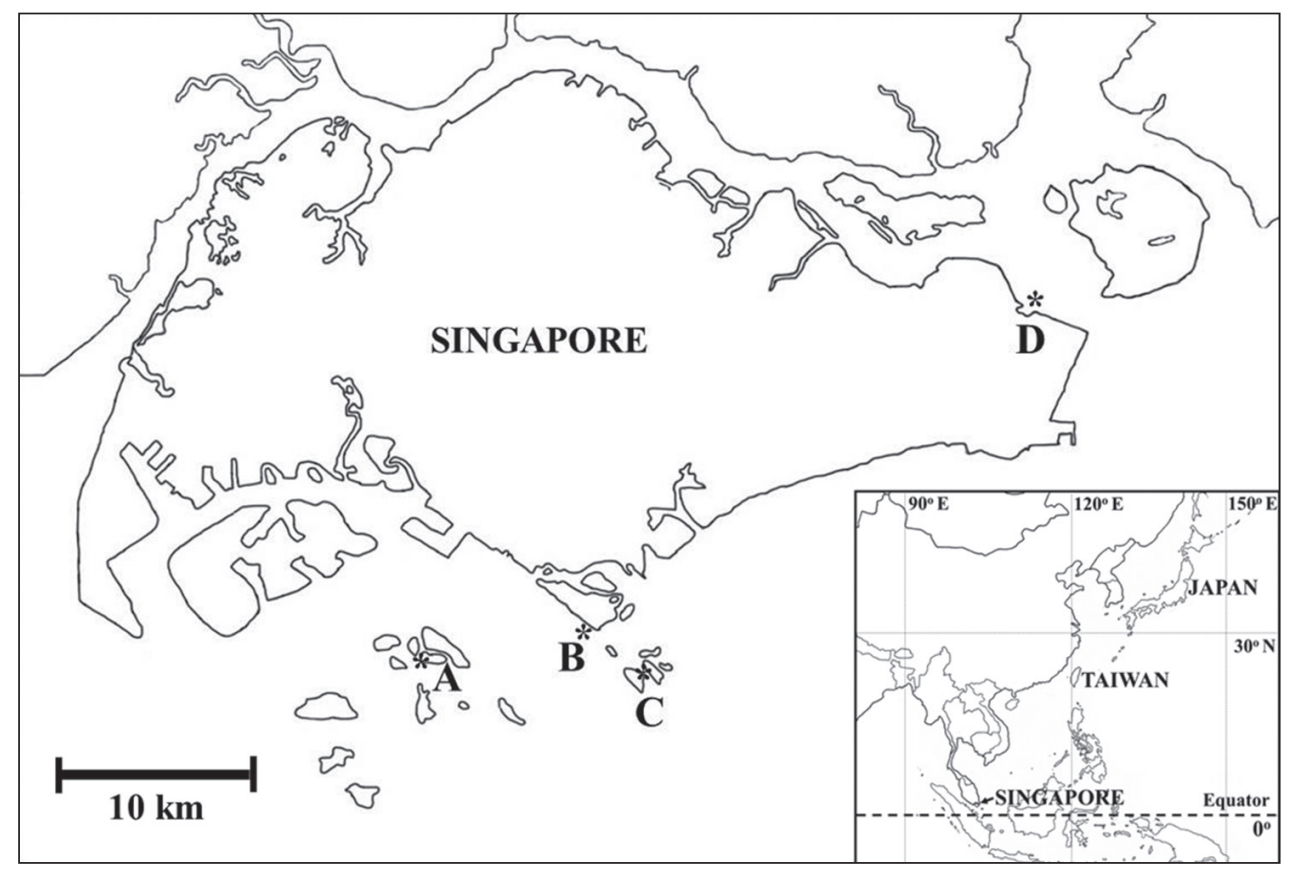

Figure I. Collection sites of photosymbiotic ascidians in Singapore. A Pulau Semakau B Sentosa C St. John's Island and D Changi Beach.

Changi Beach, Pulau Semakau, Sentosa, and St. John's Island (Fig. 1). The habitats consisted of sand beach, seagrass meadow, coral rubble, sheltered beach and coral reefs. The Changi Beach is a beach park located at the northeastern of Singapore. The park is approximately $3.3 \mathrm{~km}$ long with stretches of sandy beaches and a lot of seagrass. Pulau Semakau is located at the south of the main island of Singapore. There is a vast seagrass meadow and a wide zone of coral rubble with various marine lives and an enormous area rich in wildlife. Sentosa is a popular island resort in Singapore that includes a $2 \mathrm{~km}$ long sheltered beach. St. John's Island is one of the Southern Islands in Singapore. The hilly island is transformed into a tranquil getaway. Coral reefs and seagrass bed scatter in the zone. Specimens were anesthetized with menthol and $0.37 \mathrm{M} \mathrm{MgCl}_{2}$ for approximately $2 \mathrm{~h}$, and then fixed with $10 \%$ formalin-seawater. The fixed colonies were dissected under a binocular stereomicroscope and a compound microscope equipped with differential interference contrast optics. In some photomicrographs, several images were combined to increase the depth of field using the post-processing image software Helicon Focus Pro 4.2.2 (Helicon Soft, Ltd., Kharkov, Ukraine). Taxa were mainly identified following Kott (2001), Monniot and Monniot (2001), and Hirose and Su (2011). All of the specimens examined were deposited in the Raffles Museum of Biodiversity Research, Singapore (RMBR) or some of those were deposited in the National Museum of Natural Science, Taiwan (NMNS). 


\section{Results}

The present report describes the occurrence of didemnid ascidians harboring prokaryotic algae from Pulau Semakau, Sentosa and St. John's Island, Singapore. In total, five species were collected, two of which were new records for Singapore. Their occurrences at each site and dates are listed in Table 1. No photosymbiotic species were found at Changi Beach.

\section{Trididemnum cyclops Michaelsen, 1921}

Trididemnum symbioticum (Peres, 1962)

Specimens examined. ZRC-TUN-0012 (St. John's Island, subtidal at depth $0.5 \mathrm{~m}$ ).

Colonies are oval or irregularly shaped cushions of 2-6 $\mathrm{mm}$ on the long axis (Fig. 2A). Each zooid has a black dot, due to a pigment mass at the top of the endostyle (Fig. 2B). Berry-like spicules are distributed in the colonial margin and basal tunic, while they are rarely found in the surface tunic. Spicules are up to $40 \mathrm{~mm}$ in diameter (Fig. 2C). The biased distribution of the spicules allows the symbionts to receive sunlight for photosynthesis.

\section{Diplosoma simile (Sluiter, 1909)}

Diplosoma midori (Tokioka, 1954)

Leptoclinum midori Tokioka, 1954

Leptoclinum simile Sluiter, 1909

Specimens examined. NMNS-7027-001, NMNS-7027-002, ZRC-TUN-0001 and ZRC-TUN-0015 (Pulau Semakau, subtidal at depth $0.5 \mathrm{~m}$ ), ZRC-TUN-0011 (St. John's Island, subtidal at depth $0.5 \mathrm{~m}$ ), ZRC-TUN-0009 (Sentosa, subtidal at depth $0.5 \mathrm{~m}$ )

Colonies are irregularly shaped sheets about $2 \mathrm{~mm}$ thick without spicules (Fig. 2D). They are entirely green due to the Prochloron cells in the common cloacal

Table I. Distribution records of photosymbiotic didemnid ascidians in Singapore.

\begin{tabular}{l|c|c|c|c|c|c|c}
\hline Location & Changi Beach & \multicolumn{3}{|c|}{ Pulau Semakau } & \multicolumn{2}{c}{ St. John's Island } & Sentosa \\
\hline Date & 2011 Nov & 2009 Dec & 2010 May & 2011 Nov & 2010 May & 2011 Nov & 2010 April \\
\hline Trididemnum cyclops & & & & & + & & \\
\hline Diplosoma simile & & & + & + & + & & + \\
\hline Lissoclinum bistratum & & + & + & + & & & + \\
\hline Lissoclinum punctatum & & & + & + & + & & \\
\hline Lissoclinum timorense & & + & + & + & & & \\
\hline
\end{tabular}


cavities. The thorax has four stigmatal rows: there are six stigmata in the first (top), second, and third row and five stigmata in the fourth row (bottom). The retractor muscle emerges from the bottom of the thorax (Fig. 2E). Testis and/or egg are found in some zooids, and vas deferens is uncoiled. Kott (1982) reported this species from Singapore. This is one of the most common species in the didemnid-Prochloron obligate symbioses in the tropical Pacific, and it has also been recently found in Caribbean Panama (Hirose et al., 2012).

\section{Lissoclinum bistratum (Sluiter, 1905)}

Didemnum bistratum Sluiter, 1905

Didemnum gottschaldti Tokioka, 1950

Didemnum pulvinum Tokioka, 1954

Leptoclinum bistratum (Sluiter, 1905)

Lissoclinum pulvinum (Tokioka, 1954)

Specimens examined. NMNS-7027-003, NMNS-7027-004, ZRC-TUN-0002, ZRC.TUN.0004, ZRC-TUN-0007, ZRC-TUN-0008 and ZRC-TUN-0014 (Pulau Semakau, subtidal at depth $0.5 \mathrm{~m}$ ), ZRC-TUN-0010 (Sentosa, subtidal at depth $0.5 \mathrm{~m}$ ).

Colonies are oval cushions of $4 \mathrm{~mm}$ on the long axis (Fig. 2F). The photosymbiont Prochloron gives the colonies a green color, while the colonial margin and bottom are white due to dense aggregations of globular spicules in the tunic (Fig. 2G). The thorax has four stigmatal rows. It is difficult to count accurately the number of stigmata owing to the distortion of thoraxes caused by the shrinkage of zooids upon fixation. There are about seven stigmata in each row. Some zooids have a testis with an uncoiled vas deferens (Fig. 2H). Kott (1982) reported this species from Singapore.

\section{Lissoclinum punctatum Kott, 1977}

Specimens examined. NMNS-7027-007, ZRC-TUN-0005 and ZRC-TUN-0016 (Pulau Semakau, subtidal at depth $0.5 \mathrm{~m}$ ), ZRC-TUN-0013 (St. John's Island, subtidal at depth $0.5 \mathrm{~m}$ )

Colonies are irregularly shaped sheets about $2 \mathrm{~mm}$ thick (Fig. 2I). Globular spicules aggregate around each zooid, which is enclosed in a capsule of white spicules (Fig. 2J). Many Prochloron cells are distributed in both cloacal cavities and tunic cells (tunic phycocytes) (Fig. 2K; also see Hirose et al. 1996). We could not examine the zooids in further detail because of the shrinkage of the specimens. Kott (1982) reported this species from Singapore. 

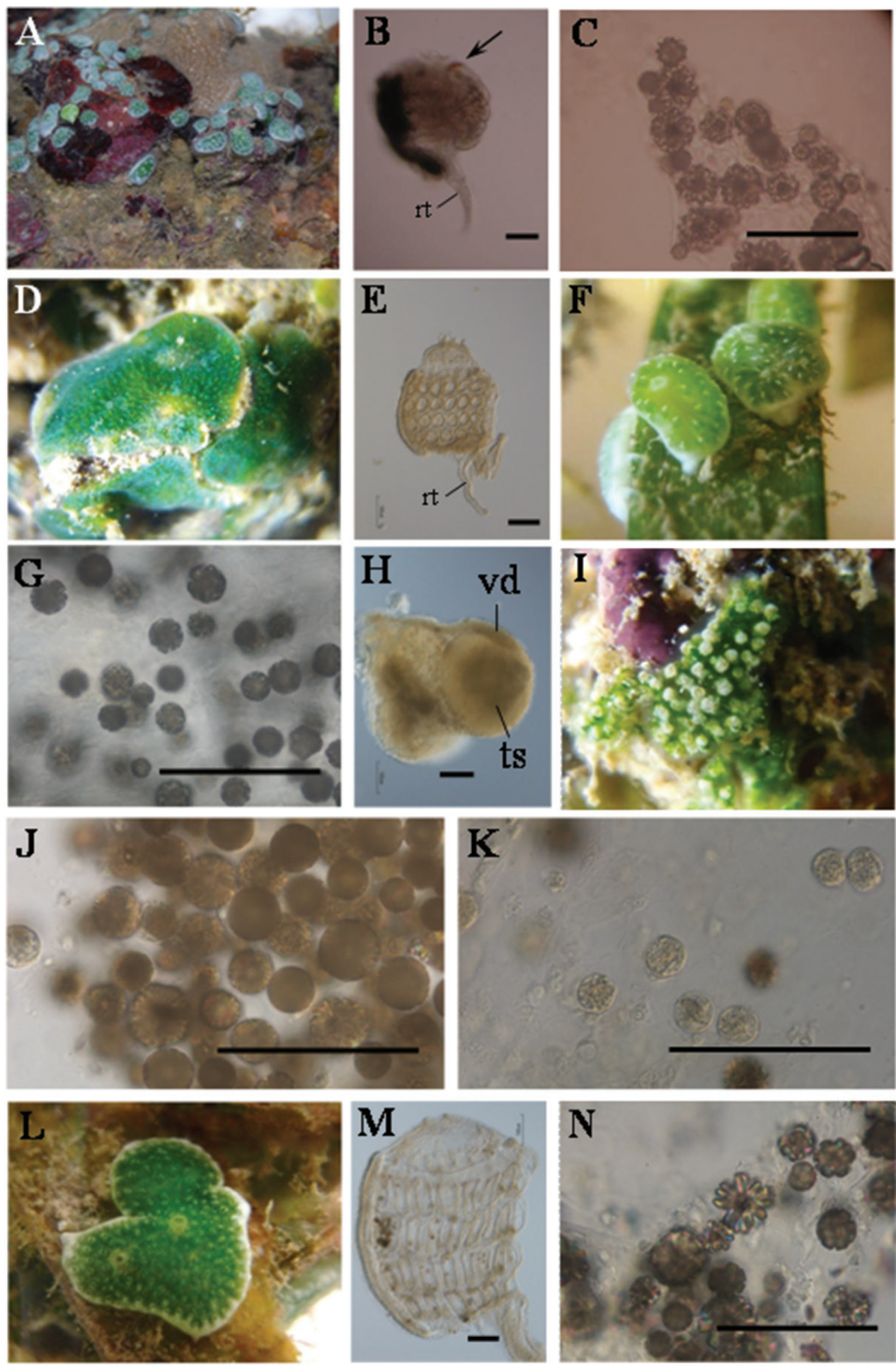


\section{Lissoclinum timorense (Sluiter, 1909)}

Didemnum timorensis Sluiter, 1909

Didemnum voeltzkowi Michaelsen, 1920

Lissoclinum timorensis (Sluiter, 1909)

Lissoclinum voeltzkowi (Michaelsen, 1920)

Specimens examined. NMNS-7027-005, NMNS-7027-006, ZRC-TUN-0003, ZRC-TUN-0006 and ZRC-TUN-0017 (Pulau Semakau, subtidal at depth $0.5 \mathrm{~m}$ )

Colonies are irregularly shaped sheets about $2-5 \mathrm{~mm}$ thick (Fig. 2L). The colonies are green due to Prochloron cells distributed in the common cloacal cavities, while the colonial margin and bottom are white due to the dense distribution of stellate and globular spicules. In the five zooids we examined, the thorax had four stigmatal rows: there were seven stigmata in the first row (top), eight in the second row, seven in the third row, and five or six in the fourth row (bottom) (Fig. 2M). Gonads are not found in the present specimens. There are globular spicules in the tunic (Fig. 2N). The presence of stellate spicules easily distinguishes the present species from L. bistratum, which lacks these spicules. However, Monniot \& Monniot (2001) proposed to regard $L$. timorense as a junior synonym of $L$. bistratum, because the two species differ only in the shape of spicules and there are no distinctive features in the zooids and larvae. The phylogenetic trees established using the partial sequences of cytochrome oxidase subunit I gene did not discriminate the two species, which are distinguished only by the spicule shapes (Hirose et al., 2010).

\section{Discussion}

Five photosymbiotic ascidians were recorded in the present survey, including three species previously observed by Kott (1982) and two new records in Singapore. There were

Figure 2. Photosymbiotic ascidians collected. A Trididemnum cyclops, St. John's Island, Singapore (Depth $=0.5 \mathrm{~m})$. Colonies are 2-6 $\mathrm{mm}$ on the long axis B Thorax of Trididemnum cyclops. Arrows indicate the endostylar pigment cap. Scale bar $=100 \mathrm{~mm}$. C Tunic spicules in the tunic of Trididemnum cyclops. Scale bar $=100 \mathrm{~mm}$ D Diplosoma simile, Pulau Semakau, Singapore $($ Depth $=0.5 \mathrm{~m})$. Colonies are approximately $15 \mathrm{~mm}$ in diameter E Thorax of Diplosoma simile (left view). Scale bar $=100 \mathrm{~mm}$ F Lissoclinum bistratum, Pulau Semakau, Singapore (Depth $=0.5 \mathrm{~m}$ ). Colonies are approximately $5 \mathrm{~mm}$ in diameter $\mathbf{G}$ Tunic spicules in the tunic of Lissoclinum bistratum. Scale bar $=100 \mathrm{~mm} \mathbf{H}$ A testis with an uncoiled vas deferens of Lissoclinum bistratum. Scale bar $=100 \mathrm{~mm} \mathbf{I}$ Lissoclinum punctatum, Pulau Semakau, Singapore (Depth $=0.5 \mathrm{~m}$ ). Colonies are approximately $10 \mathrm{~mm}$ in diameter $\mathbf{J}$ Tunic spicules in the tunic of Lissoclinum punctatum. Scale bar $=100 \mathrm{~mm}$ K Tunic phycocytes of Lissoclinum punctatum. Scale bar $=100 \mathrm{~mm} \mathbf{L}$ Lissoclinum timorense, Pulau Semakau, Singapore (Depth $=0.5 \mathrm{~m}$ ). Colonies are approximately $10 \mathrm{~mm}$ in diameter $\mathbf{M}$ Thorax of Lissoclinum timorense (left view) $\mathbf{N}$ Tunic spicules in the tunic of Lissoclinum timorense. Scale bar $=100 \mathrm{~mm}$. rt, retractor muscle; ts, testis; vd, vas deferens. 
four species in Pulau Semakau, three species on St. John's Island and two species in Sentosa, but no photosymbiotic species were found at Changi Beach. The five species listed here might be far from the entire coverage of the photosymbiotic ascidian fauna in Singapore, because the present survey was conducted over a very short period of time and at only four sites. It is expected that more species still remain to be recorded.

Once, there were over 60 offshore islands and patch reefs around Singapore, most of which were situated south of mainland Singapore. However, since the mid 1970s, Singapore has been undergoing coastal reclamation. As its population grows until more than four million, the Singapore government faces problem in providing ample land. Some of offshore islands in Singapore have been deformed or enlarged by some coastal reclamation projects. Many of the coral reef organisms were smothered by reclamation, while others were severely affected by the resulting increase in water turbidity. The high turbidity of waters restricts light penetration, and determines the maximum distribution depth for corals and photosymbiotic ascidians. Visibility has been reduced from $10 \mathrm{~m}$ in the 1960s to $2 \mathrm{~m}$ or less to date (Coral Reefs of Singapore, http://coralreef. nus.edu.sg/). As a result, up to $60 \%$ of the live coral cover has been lost in Singapore since 1986 (Chou 2006). We had recorded three species (Trididemnum cyclops, Diplosoma simile and Lissoclinum punctatum) at St. John's Island in May 2010, but since then we were unable to find any photosymbiotic ascidians at the island. There were also two species of photosymbiotic ascidians, Diplosoma simile and Lissoclinum bistratum, in Sentosa. Interestingly, no photosymbiotic species were found at Changi Beach in the present survey, although its latitude is comparable with that of Pulau Semakau. Although these results do not conclusively demonstrate the absence of photosymbiotic ascidians at Changi Beach, photosymbiotic species must be rare there.

The coastal environment of Singapore is limited and currently severely affected by coastal development and the port industry, which is one of the biggest economic businesses in the country. Harbor limits occupy most of the territorial waters, and reclamation has transformed considerably almost the entire southern and northeastern coasts of the main island (Chou and Goh 1998). Most of the coastal waters are filled with suspended particles that block photosynthetic activities of marine organisms. When these particles sink, they settle over sessile organisms, such as photosymbiotic ascidians, and adversely affect their metabolism and growth (Dionisio-Sese et al. 2001). In 1999, when the last remaining landfill on Singapore's mainland was exhausted, the Semakau Landfill was created by enclosing Pulau Semakau and a small adjacent island (Pulau Sakeng) with a rock bund. However, the original Pulau Semakau, which was not affected by the landfill construction, has an enormous intertidal area rich in amazing wildlife. There is a wide zone of coral rubble with various marine lives, leading to the coral reefs that line the edge of the island. Clean waters in Pulau Semakau provide a better environment for the growth of photosymbiotic ascidians that are able to perform both photosynthesis and suspension feeding. In Pulau Semakau, we recorded four species of photosymbiotic ascidians, namely, Diplosoma simile, L. bistratum, L. punctatum and L. timorense and it is the area in Singapore with the greatest variety of photosymbiotic ascidians. 
Table 2. Distribution records of photosymbiotic didemnid ascidians in Japan, Taiwan and Singapore.

\begin{tabular}{l|c|c|c}
\hline Location & Japan & Taiwan & Singapore \\
\hline Didemnum molle & + & + & \\
\hline Diplosoma aggregatum & + & + & \\
\hline Diplosoma gumavirens & + & + & \\
\hline Diplosoma ooru & + & + & \\
\hline Diplosoma simile & + & + & + \\
\hline Diplosoma simileguwa & + & + & \\
\hline Diplosoma variostigmatum & + & & \\
\hline Diplosoma virens & + & & \\
\hline Diplosoma watanabei & + & + & \\
\hline Lissoclinum bistratum & + & & \\
\hline Lissoclinum midui & + & & \\
\hline Lissoclinum patella & + & & + \\
\hline Lissoclinum punctatum & + & & + \\
\hline Lissoclinum timorense & + & & \\
\hline Lissoclinum triangulum & + & + & \\
\hline Trididemnum clinides & + & & \\
\hline Trididemnum cyclops & + & & \\
\hline Trididemnum miniatum & + & \\
\hline Trididemnum nubilum & + & \\
\hline
\end{tabular}

(Hirose and Nozawa 2011; Hirose and Su 2011; Hirose in press, and references therein)

More than 20 photosymbiotic species are known to be distributed in Japan, mainly in the Ryukyu Archipelago (Hirose in press, and references therein) and 10 species in total were recorded in Taiwan (Hirose and Nozawa 2011, Hirose and Su 2011) (Table 2). Only five species were recorded in Singapore, and each of them had also been recorded in Japan. Among them, Diposoma simile, Lissoclinum bistratum and Trididemnum cyclops were also recorded in Taiwan. The climate of Singapore is typically wet equatorial, with high temperature and high annual precipitation. The average sea surface temperature is about $29^{\circ} \mathrm{C}$. The optimum temperature for Prochloron is $35^{\circ}$ to $40^{\circ} \mathrm{C}$, as the temperature range for proper photosynthesis is between $20^{\circ} \mathrm{C}$ and $45^{\circ} \mathrm{C}$ (Dionisio-Sese et al. 2001). Alberte et al. (1986) also showed that photosynthesis of Prochloron was fairly sensitive to temperature; the photosynthetic activity at $25^{\circ} \mathrm{C}$ is only half of that at $30^{\circ} \mathrm{C}$, and it falls almost to 0 at $20^{\circ} \mathrm{C}$. This sensitivity of Prochloron to low temperature may be a prime factor limiting the distribution of this species to tropical waters.

\section{Acknowledgments}

The authors are indebted to Dr. Tan Koh Siang, Head of Marine Biology and Ecology Group, Tropical Marine Science Institute, National University of Singapore, and Dr. 
Li-Lian Liu, Professor of Institute of Marine Biology, National Sun Yat-sen University, Taiwan, who encouraged us and supported our survey. The present study was partly supported by Pilot Overseas Internships, sponsored by the Ministry of Education Taiwan. The collection of material in the subtidal of Singapore was granted by the National Biodiversity Centre, Singapore (NP/RP 11-091).

\section{References}

Berrill NJ (1950) The Tunicata, with an account of the British species. London: Ray Society.

Chou LM (2006) Marine habitats in one of the world's busiest harbours. In: Wolanski E

(Ed) The Environment in Asia Pacific Harbours. Springer, Dordrecht, 377-391. doi: 10.1007/1-4020-3655-8_22

Dionisio-Sese ML, Maruyama T, Miyachi S (2001) Photosynthesis of Prochloron as affected by environmental factors. Marine Biotechnology 3: 74-79. doi: 10.1007/s101260000062

Hirose E (in press) Didemnid ascidians harboring cyanobacteria from Kumejima Island and Tonakijima Island, Ryukyu Archipelago, Japan. Biological Magazine Okinawa.

Hirose E, Hirose M (2011) A new didemnid ascidian Lissoclinum midui sp. nov. from Kumejima Island (Okinawa, Japan), with remarks on the absence of a common cloacal system and the presence of an unknown organ. Zoological Science 28: 462-468. doi: 10.2108/ zsj. 28.462

Hirose E, Nozawa Y (2011) Photosymbiotic ascidians from Kenting and Lyudao in Taiwan. Zoological Studies 49: 681-687.

Hirose E, Oka AT (2008) A new species of photosymbiotic ascidian from the Ryukyu Archipelago, Japan, with remarks on the stability of stigma number in photosymbiotic. Diplosoma species. Zoological Science 25: 1261-1267. doi: 10.2108/zsj.25.1261

Hirose E, Su SW (2011) A new record of a photosymbiotic ascidian from Kenting, Taiwan with a key to the photosymbiotic species of the genus Diplosoma recorded in the western Pacific. Collection and Research 24: 83-86.

Hirose E, Maruyama T, Cheng L, Lewin RA (1996) Intracellular symbiosis of a photosynthetic prokaryote, Prochloron sp, in a colonial ascidian. Invertebrate Biology 115: 343-348. doi: $10.2307 / 3227023$

Hirose E, Oka AT, Hirose M (2009a) Two new species of photosymbiotic ascidians of the genus Diplosoma from the Ryukyu Archipelago with partial sequences of the COI gene. Zoological Science 26: 362-368. doi: 10.2108/zsj.26.362

Hirose E, Uchida H, Murakami A (2009b) Ultrastructural and microspectrophotometric characterisation of multiple species of cyanobacterial photosymbionts coexisting in the colonial ascidian Trididemnum clinides (Tunicata, Ascidiacea, Didemnidae). European Journal of Phycology 44: 365-375. doi: 10.1080/09670260802710269

Hirose E, Turon X, López-Legentil S, Erwin PM, Hirose M (2012) First records of didemnid ascidians harboring Prochloron from Caribbean Panama: Genetic relationships between Caribbean and Pacific photosymbionts and host ascidians. Systematics and Biodiversity 10: 435-445. doi: 10.1080/14772000.2012.735716 
Hirose M, Hirose E (2009) DNA-barcoding in photosymbiotic species of the genus Diplosoma (Ascidiacea: Didemnidae) and a description of a new species from the southern Ryukyus, Japan. Zoological Science 26: 564-568. doi: 10.2108/zsj.26.564

Hirose M, Tochikubo T, Hirose E (2010) Taxonomic significance of tunic spicules in photosymbiotic ascidians: a quantitative and molecular evaluation. Journal of the Marine Biological Association of the United Kingdom 90: 1065-1071. doi: 10.1017/S0025315409991263

Kott P (2001) The Australian Ascidiacea part 4, Aplousobranchia (3), Didemnidae. Memoirs of the Queensland Museum 47: 1-408.

Lewin RA, Cheng L (1989) Prochloron, a microbial enigma. New York: Chapman \& Hall. doi: 10.1007/978-1-4613-0853-9

Millar RH (1975) Ascidians from the Indo-West Pacific region in the Zoological Museum, Copenhagen. (Tunicata, Ascidiacea). Steenstrupia 3: 205-336.

Millar RH (1988) Ascidians collected during the International Indian Ocean Expedition. Journal of Natural History 22: 823-848. doi: 10.1080/00222938800770541

Monniot F, Monniot C (2001) Ascidians from the tropical western Pacific. Zoosystema 23: 201-383.

Oka AT, Suetsugu M, Hirose E (2005) Two new species of Diplosoma (Ascidiacea: Didemnidae) bearing prokaryotic algae Prochloron from Okinawajima (Ryukyu Archipelago, Japan). Zoological Science 22: 367-374. doi: 10.2108/zsj.22.367

Parry DL, Kott P (1988) Co-symbiosis in the ascidiacea. Bulletin of Marine Science 42: 149-153. 